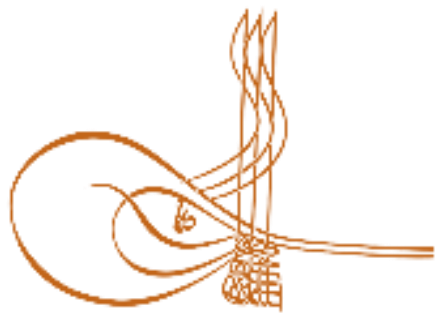

www.turkishstudies.net/social
Turkish Studies - Social Sciences

eISSN: $2667-5617$

Research Article / Araştırma Makalesi

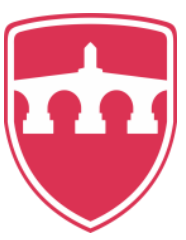

INTERNATIONAL

BALKAN

UNIVERSITY

Sponsored by IBU

\title{
Mevlâna'nın Eserlerinde Bir Yükseliş Motifi Olarak Zühre
}

Zohra as an Ascension Motif in the Works of Rumi

\author{
Nermin Öztürk*
}

\begin{abstract}
The story of the star that is known as "Zohra" in the Eastern classics fundamentally differs from the usual stories of women which are often filled with unfortunate events and downfalls. The great Turkish thinker and mystic Rumi mentions Zohra in various ways in his writings. According to him, Zohra is a woman who rises in the skies to evolve and become a star. This is in contrast with the story of Adam and Eve in Abrahamic religions which is about the downfall from heavens and condemnation to the clay. Zohra has been replaced with angels in the sky. The names of these angels are mentioned in the Qur'an as Harut and Marut. They saw that the people of the earth had sinned and complained to God, and God sent them to the earth, giving them the emotions that caused people to sin. The angels who met Zohra here fell in love with her and wanted to be together. Zohra made good use of this opportunity and somehow learned the secret of trapping them and rising to the sky. As Zohra rose up into the sky and turned into a star, they were hanged upside down in the Babylonian well. Rumi mentions Zohra in close relation with musical instruments, singing, wine, love and beauty. The sacred day of Zohra is Friday. Friday is also the blessed day for Muslims. Taking the fact into account that the objective of the mysticism is the love of God, the profound message to be delivered in this instance can be interpreted as the mental inebriety, joy and rapture of the human soul, independent of and in contrast to the superficial feminine figure that is associated with wine, musical instruments and mundane joy. Ascending to the sky is an expression of being close to God. The achievement of this by a woman is due to the symbolization of the nafs with the woman in Sufism.
\end{abstract}

Structured Abstract: We are all familiar to the events of "ascension" which are encountered in religions and mythologies. The Muslims know the story of one night journey of prophet Muhammed to the seven skies, the Christians know how the Christ returned to the life and rose up to sky after three days of his death and The Jews, according to the statements in Tanah, know that Elijah is lifted up by the violent winds and that Idris (Enoch) walked with God and disappeared from sight. Apart from these, this motif is found along within the religions- such as Hinduism, Buddhism, Sabiism, Maniheism and Zoroastrianism-, in the Sumerian, Babylonian and Ancient Greek traditions and in the religions of indigenous tribes in various parts of the world. This incident is an extraordinary incident of ascending to the outside world with the earthly body. And in many cases, in many religious traditions, it is believed that, after death, the body will be abandoned and the spirit is

\footnotetext{
* Doç. Dr. Necmettin Erbakan Üniversitesi, Ahmet Keleşoğlu İlahiyat Fakültesi, Felsefe ve Din Bilimleri Bölümü Assoc. Prof. Dr. Necmettin Erbakan University, Ahmet Kelesoglu Faculty of Theology, Department of Philosophy and Religious Sciences

ORCID 0000-0003-2757-5798

mn.18@hotmail.com,nozturk@konya.edu.tr

Cite as/ Atıf: Öztürk, N. (2020). Mevlâna'nın eserlerinde bir yükseliş motifi olarak Zühre, Turkish Studies - Social, 15(3), 1411-1422. https://dx.doi.org/10.29228/TurkishStudies.42046

Received/Geliş: 06 March/Mart 2020

Accepted/Kabul: 25 April/Nisan 2020

Copyright $@$ INTAC LTD, Turkey
} 
raised up to the sky. Those who have experienced the 'ascension' are not ordinary figures but are elite people such as prophets, religious founders, kings, priests, shamans and almost all of them are men. Whereas the hero of the subject we will discuss here, is feminine and an ordinary person.

For us, the most interesting feature in this story was the upsurge of the female image that we are accustomed to seeing with declines, usually with negativity, as in the story of Adam and Eve. Another example that can be given to the ascension of a woman is perhaps the Assumption of Mary in Catholic and Orthodox Christianity. Though this resurrection was not when she was alive, it is believed that only after her life came to an end, had she been physically and spiritually raised to the sky, to the Christ- her son- and Mary will return to earth with Jesus on the Day of Resurrection. Though in many Islamic sources related to the Zohra's tale, the story is told in a somewhat similar way, here we chose only the works of Rumi. His other books in addition to the Masnawi were reviewed, trying to evaluate the findings with the phenomenal method while investigating the concept of 'woman'.

The story of Zohra actually serves as an interpretation of the Bakara verse 102. In this verse, the two angels who teach people magic, Harut and Marut are mentioned but Zohra is not mentioned. It can be seen in Rumi's works that Zohra is associated with these angels.

According to story when the angels complain to Allah about human beings that they have sinned, Allah tells them that they cannot do better under the same circumstances. The angels claim that under no circumstances they will act like the children of Adam. Then Allah gives the lust of mankind to the two angels whom they have chosen among themselves, Harut and Marut, and send them to Babylon. They remain on the earth every day, and in the evening, they go back to the sky by remembering the greatest name of Allah. One day the angels meet a very beautiful woman named Zohra, they fell in love with her and enjoy themselves to the full extent. As a condition for being with them, she asks them to teach her what they read and utter as they go back to sky. They do not agree it. The woman then requires them to drink liquor, either to kill her husband, or to worship an idol. Harut and Marut agree to drink as it is the lightest of the three conditions. But when they drank the liquor, they did worship the idol and killed the woman's husband. And in this time of their drunkenness she learns the prayer they read in order to ascend to the sky and she ascends to the sky. And Allah turns it into a bright star in the sky, and leaves it there as a sign for human beings. Here Zohra (Star of the Shepherd, Venus) is this woman. As a punishment, those two angels are hanged upside down into a well filled with fire in Babylon.

According to Rumi, Harut and Marut are angels doomed to stay in a well because of their lust. They teach people how to cast and solve spells. But before they do that, they warn people to give up this particular interest, they admit that this wisdom actually teaches people to suffer and test them. Of course, in order for the humans to be tested, they must have their free will.

The conclusions we have drawn from the information obtained by reviewing most of Rumi's works may be listed as follows: 1- The story of Zohra's rise to heaven and turning into a star is an example of the process of rising to spiritual plane or heaven in many religious traditions. In fact, this rise is always accompanied by a fall. Because there is no rise without falling, just like there is no day without night. Thus, the story of Zohra actually encompasses a story of decline. The fall of the angels, Harut and Marut means the rise of Zohra. Therefore, Rumi mentions the name of Zohra together with these angels. The starting place of the first decline and rise is symbolized by the city of Babylon. What causes Harut and Marut to fall is their defeat in their lust, their pride and arrogance, and their inability to make a decision. On the other hand, the reason for the rise of Zohra is that she was ashamed, regretful and repentant because of the crime she committed. Repentance is the starting point in spiritual ascension. In this context, which started with Zohra's embarrassment that resulted in her metamorphosis into a star; metaphorically, the spiritual journey of the man called "seyr" in Islam Sufism and the rank / degree reached were explained. 2- This rank is the rank of love and beauty. The acquisition of this rank by a woman is due to the symbolization of the soul with the woman in Sufism. In the text, we also mentioned who Rumi calls 'female'. The magnificence of this station (maqam) is symbolized by the beauty of Zohra, and the accompanying behaviors are symbolized by drunkenness and music. 3- The day of Zohra is Friday. This is the "gathering day" for Muslims. Therefore, the rank of Zohra is also a gathering place, that is, the reunification of the dispersed mind and the emotions that are scattered by the distraction of the worldly matters. This is a feast day for the soul filled with joy and happiness.

Turkish Studies - Social, 15(3) 
The language of religion is a metaphorical one. Thus, rather than a woman's tale, the story of Zohra is everyone's story on reaching God, whether it is a man or a woman. In order to understand the messages that religious stories try to give; it is important to see the images in them as reflections of the spiritual potential within each of us. The states of our spirituality, that is, beyond physics, are described in religions or mythologies by transforming them into physical realities in a way that we can perceive and grasp with our five senses. The goals of mystical traditions are to help people reach a deeper awareness of God and the hell.

Keywords: History of Religions, Zohra star, feminine concept, Rumi, ascension.

Öz: Doğu klasiklerinde Zühre olarak karşımıza çıkan yıldızın hikâyesi daha çok düşüşlerle ve olumsuzluklarla yan yana görmeye alışkın olduğumuz kadın söylemlerinin tersine bir durumu anlatır. Büyük Türk düşünürü ve mutasavvıfı Mevlâna da eserlerinde zaman zaman Zühre'den farklı şekillerde bahseder. Ona göre Zühre göğe yükselerek şekil değiştiren ve yıldıza dönüşen bir kadındır. Bu durum semavi dinlerdeki Âdem ve Havva hikâyesindeki düşüşün ve balçığa mahkûm oluşun tersine bir durumdur. Zühre gökteki meleklerle yer değiştirmiştir. Kur'an'da bu meleklerin ismi Harut ve Marut olarak geçer. Onlar yeryüzündeki insanların çok günah işlediklerini görüp Tanrıya şikayetçi olmuşlar, Tanrı da bunun üzerine onlara insanların günah işlemelerine sebep olan duyguları vererek yeryüzüne göndermiştir. Burada Zühre ile karşılaşan melekler ona âşık olmuş ve birlikte olmak istemişlerdir. Zühre bu firsatı iyi değerlendirmiş, bir şekilde onları tuzağa düşürüp göğe yükselmenin sırrını öğrenmiştir. Zühre gökyüzüne yükselip bir yıldıza dönüşürken onlar Babil kuyusunda başaşağı vaziyette asılı kalmışlardır. Mevlâna Zühre'den bahsederken sıklıkla müzik aletlerinden, çalıp söylemekten, şaraptan, aşktan ve güzellikten söz eder. Zühre'nin kutsal günü ise Cuma'dır. Cuma aynı zamanda Müslümanların da mübarek günüdür. Tasavvufun konusunun Allah aşkı olduğu göz önüne alınırsa yüzeysel olarak kadın figürü üzerinden çenkle müzikle şarapla birlikte verilmeye çalışılan mesajın derin anlamıyla fiziksel cinsiyetten tamamıyla bağımsız, ruhun manevi sarhoşluk, neş'e ve cezbe haline işaret ettiğini söylemek mümkündür. Göğe yükselmek Tanrı'ya yakın olmanın ifadesidir. Bunun bir kadın tarafından başarılması ise tasavvufta nefsin kadın ile simgelenmesinden ötürüdür.

Anahtar Kelimeler: Dinler Tarihi, Zühre yıldızı, dişil, Mevlâna, yükseliş.

\section{Giriş}

Dinlerde ve mitolojilerde karşımıza çıkan "göğe yükselme" olaylarına hemen hepimiz aşiyanızdır. Müslümanlar Hz. Muhammet'in miracını, Hıristiyanlar Hz. İsa'nın ölümünden üç gün sonra dirilip göğe yükselişini, Yahudiler Tanah’taki ifadelere göre İlyas'ın (Elijah) şiddetli rüzgarlar tarafından göğe kaldırılışını (II. Krallar, 2:11), İdris'in (Enoch) Tanrı ile yürüyüp gözden kaybolduğunu (Tekvin, 5: 24) iyi bilirler. Bunlardan başka Hinduizm, Budizm, Sabiilik, Maniheizm ve Zerdüştilik gibi dinler ile Sümer, Babil ve Eski Yunan geleneğinde ve dünyanın muhtelif yerlerindeki yerli kabile dinlerinde bu motife rastlanır. Olayı sıra dışı kılan dünyalık beden ile göğe çıkma hadisesidir. Aksi takdirde zaten pek çok dini gelenekte ölümden sonra bedenin terk edilerek ruhen göğe yükselineceğine inanılmaktadır. Göğe yükselme deneyimini yaşayanlar ise sıradan şahsiyetler olmayıp peygamberler, din kurucuları, krallar, rahipler, şamanlar gibi seçkin kişilerdir ve hemen hepsi erkektirler. Oysa bizim burada ele alacağımız konunun kahramanı bir kadındır ve sıradan birisidir. Bizim açımızdan konuyu ilginç kılan ve asıl başlangıç noktamız olan husus da budur.

Genellikle olumsuzluklarla ve Âdem ile Havva'nın hikâyesinde olduğu gibi düşüşlerle görmeye alışkın olduğumuz kadın imgesi Zühre'nin hikâyesinde yükselişle anılmıştır. Gerçi kadının göğe yükselişine verilebilecek bir örnek belki Katolik ve Ortodoks Hıristiyanlıktaki Hz. Meryem'dir ama (Assumption of Mary) bu doğmada onun yaşarken değil öldükten sonra bedenen ve ruhen göğe çekildiğine, kıyamet günü İsa ile birlikte yeryüzüne döneceğine inanılmaktadır (Yitik, 2000: 65). Aslında Zühre'nin hikâyesi İslami literatürde pek çok tefsir ile edebi ve tarihi eserlerde işlenmiştir. Fakat biz konuyu sadece Mevlana'nın eserleri bağlamında ele aldık, Mesnevi'nin yanı sıra onun diğer eserlerini de inceledik, bulguları fenomenolojik yöntemle değerlendirmeye çalıştık. Aşağıda

www.turkishstudies.net/social 
Zühre'nin önce yeryüzünde bir kadınken sonra nasıl göğe yükselip bir yıldıza dönüştüğünün hikâyesine ve onun diğer özelliklerine yer verilecektir.

\section{Yıldıza Dönüșen Kadın}

Zühre özellikle edebi sanatlarda aşk konusu anlatılırken sıklıkla başvurulan bir karakterdir. $\mathrm{O}$, İslami literatürde aynı zamanda gökyüzündeki gezegenlerden birinin adıdır. Gezegene ismini verenin bir kadın olduğuna inanılır. Türklerin genel olarak "Çolpan" veya "tan yıldızı" dedikleri bu yıldız Anadolu'da "Çoban Yıldızı" ya da "Sabah Yıldızı" adıyla bilinir (Çaycı, 2002: 88). Eski Türkler parlaklıklarına bakarak yıldızlara isim verdikleri için ona "işık yıldızı" anlamında "Yaruk Yulduz" demişlerdir. Anadolu'nun birçok yerinde buna benzer şekilde "Ak Yıldız" denir (Sarı, 2016: 68). Çünkü o, parlaklığından ötürü sabahları bile gözükür. Gerek halk edebiyatında gerekse dini edebiyatta anlatılan şey onun insan iken nasıl bir yıldıza dönüştügüdür. Zühre bu hikâyelerin hepsinde Harut, Marut adındaki iki meleğin yanı sıra aşk, büyü ve sarhoşlukla ilişkilendirilir.

Zühre'nin hikâyesi aslında Kur'an'ın Bakara suresi 102. ayetinin tefsiri mahiyetindedir. Bu ayette insanlara büyü öğreten Harut ve Marut adındaki iki melekten söz edilir, fakat Zühre'nin adı geçmez. Mevlâna'nın eserlerine baktığımızda onun da Zühre'yi bu meleklerle ilişkilendirdiğini görürüz. Rumi o meleklerden Harut'u, bir rubaisinde, Zühre ile aynı mısrada zikreder:

Can, gündüz yılana, gece balı̆̆a benzer!

Bak ki sen nasıl bir can ile yoldaş olmuşsun?

Gâh sihir meleği olan Harut ile kuyudasın,

Gâh Zühre yıldızının ortasında aya bekçilik yaparsın. (Gençosman, 1974: rubai no:1505) ${ }^{1}$

Mevlana'ya göre Zühre'nin yıldıza dönüşmesinde işlediği bir suçtan dolayı utanç duyması etkili olmuştur. $\mathrm{O}$, bununla ilgili mısralarında bir taraftan insan tabiatının günaha meylini, diğer taraftan utanma ve bağışlanma duygusu ile nelerin değişebileceğini gösterir. $\mathrm{VI} / \mathrm{b} .2964)$

A Gökyüzü atına binmiş güneş, a kendini hileyle yıldıza dönüştüren güzel. (Gölpınarl1, 2000:

Bir kadının kötü işten yüzü sararınca, utanınca Allah, onu çarpıp Zühre yıldızı yaptı.

Bir kadını Zühre yapmak çarpma oldu da balçık haline geliş, çarpılma değil midir? Be inatçı! (İzbudak, 2004: 1/b. 535-536)

Tövbe bineği şaşılacak bir binektir; bir solukta aşă̆glık dünyadan göğe sıçraylverir. (İzbudak, 2004: VI/ b. 467)

Dolayısıyla manevi yoldaki ya da yükselişteki ilk makam tövbedir. Tövbe, günahlardan uzak durmak ve her türlü dünyevi kaygıdan vazgeçmektir (Schimmel: 2001: 117).

Gölpınarlı yukarıda geçen Zühre ile ilgili beyitleri şerh ederken Harut ve Marut adlarındaki meleklerin insanların çok günah işlediklerinden şikâyet etmeleri üzerine Tanrı'nın “onlarda şehvet var, sizde de olsa onlara dönersiniz" dediğini söyler. Ama onlar "biz isyan etmeyiz" demişler, bunun üzerine Tanrı bu iki meleğe şehvet duygusu verip Babil'e indirmiş. Onlar burada gün boyunca hüküm sürer, isteyenlere büyü öğretir, gece olunca Tanrı'nın en büyük adını anıp göğe ağarlarmış. Derken bunlar Babil'de bir kadına âşık olmuşlar, kötülükte bulunmuşlar; hatta kadın onlara râm olmadan önce Tanrı'nın en büyük adını kendisine belletmelerini istemiş, onlar da kabul etmişler. Kadın bu adı okuyarak göğe ağmış, Tanrı da onu çarpıp Zühre yıldızı yapmışıı. Harut ile Marut'u ise dünya ya

\footnotetext{
${ }^{1}$ Mevlâna'nın eserlerinden yapılan alıntılarda farklı yazarlar tarafından hazırlanmış olan çeviriler kullanılmıştır. Bu nedenle ilgili yerlerde çevirmenlerin soyadları verilmiştir.
} 
da ahiret azabını seçmede özgür bırakmış, onlar dünya azabını tercih etmişlerdir. Bunun üzerine ikisi de Babil kuyusunda baş aşağı asılmışlardır (Gölpınarlı, 1985: I/186-187).

Kur'an'da bahsedilen ayetin dışında bu melekler hakkında bilgi yoktur. Bazı kıraat âlimleri bunlar için kullanılan ve iki melek anlamına gelen "melekeyn" kelimesini iki kral anlamına gelen "melikeyn" şeklinde okumayı tercih etmiş ve bunların insan olduklarını söylemişlerdir. İbnHazm ise bunları şeytan veya cinden iki kabile olarak yorumlamıştır. İslam âlimleri Harut ve Marut hakkında hiçbir sahih hadis olmadığını söylerler. Ahmed b. Hanbel'in Müsned'inde yukarıdaki açıklamalara benzer bir hadis vardır. Fakat bu hadise göre kadın onlarla birlikte olmasının karşılığında Allah'a ortak koşmalarını şart koşar. Melekler bunu reddeder. Bunun üzerine kadın onlardan bir çocuğu öldürmelerini ister. Melekler bunu da reddederler. Daha sonra kadın içki içmelerini ister. Harut ile Marut bu üçünün arasından en hafifi olarak gördükleri içki içme şartını kabul ederler. Ancak içkiyi içince daha önce reddettikleri her şeyi yaparlar. Kadınla zina edip çocuğu da öldürürler (Demirci, 1997: 263).

Mevlana'ya göre de Harut ve Marut şehvetleri yüzünden bir kuyuda kalmaya mahkûm olan meleklerdir. Onlar insanlara hem büyü yapmayı hem de büyü çözmeyi öğretirler. Fakat bunu yapmadan önce insanları bu sevdadan vazgeçmeleri yönünde uyarırlar, bu ilmi aslında insanları belalara uğratmak ve sınamak için öğrettiklerini itiraf ederler. Tabi, insanın sınanabilmesi için ihtiyarının elinde olması gereklidir (Gölpınarl1, 1985: V/b. 620-625). Bu noktada Mevlana'nın melek ve insan kavramlarına yaklaşımı önem arz eder. O, konu hakkında Hz. Muhammed'in bir hadisini aktarır: "Gerçekten de Yüce Tanrı melekleri yarattı, onlara akıl verdi; hayvanları yarattı, onlara şehvet verdi; Âdemoğullarını yarattı, onlara akıl da verdi, şehvet de; kimin aklı şehvetine üst olursa meleklerden yücedir o; şehveti aklından üst olursa hayvanlardan daha aşağıdır.” Mevlâna bu hadis bağlamında varlık mertebesinde yaratılmışları üçe ayırır. Bunlardan ilki yalnızca akıl mertebesinde olan meleklerdir ki, secdeden başka bir şey bilmezler. İkincisi sadece nefs/şehvet sahibi olan hayvanlardır ki Mevlâna bunu eşek ile simgeler. Üçüncüsü ise onun yarısı melek, yarısı eşek şeklinde tanımladığı insanoğludur. İnsanın hayvan olan tarafi onu aşağılara çeker, akıl olan tarafi yukarılara çeker. İnsanları da üç sınıf olarak değerlendiren Mevlâna akıl yönü ağır basanların meleklere benzediğini, nefs/şehvet yönü ağır basanların hayvanlara benzediğini söyler (Gölpınarlı, 1985: IV/b. 1497-1509). Üçüncü bir grup vardır ki, akıl ve nefs arasında büyük bir cihat içindedir (Gölpınarlı: IV/b. 1531). Canın yücelere çıkabilmek için büyük çaba gösterdiğini ifade eden Mevlâna, aklın Yüce aklı bırakması durumunda aşağılara düşeceğini ve Harut ile Marut'a benzeyeceklerini söyler. Çünkü onlar insanların hallerine, günahlarına, kötülüklerine bakıp gurura kibre kapılmışlardır (Gölpınarlı, 1985: I/b. 3344-3346).

\section{Zühre'nin Özellikleri}

Mevlâna'ya göre Zühre çok güzel bir kadındır. O, Zühre'nin güzelliğini aya ve güneşe benzeterek anlatır ki, her ikisi de göğe ait unsurlardır ve ışık ile alakalıdırlar. Mevlâna onun güzelliğini muhtelif eserlerinde şöyle ifade eder:

Zühre Ay'a eş oldu, dudu kuşu şekere. (İzbudak, 2004: I/b.252)

Ey Zühre'ye benzeyen yüzü kuşluk güneşi olan. (İzbudak, 2004: V/b. 3569)

Zengin bir adam vardı. Bu adamın da Zühre yanakll, ay yüzlü, gümüş bedenli bir kizı vardı. (İzbudak, 2004: V/b. 3716)

Zühre yıldızı gibi, Ay gibi güzelsin! (Gençosman, 1974: rubai no:1463)

Ey Zühre yıldızı gel yanaklarımı yaldızla! (Gençosman, 1974: rubai no:1141) 
Zühre güzel olduğu kadar da bir aşk kadınıdır. Güzellik ve aşk zaten hep yan yanadır. Gönül güzeli arar, ona âşık olur. Bu yüzden Zühre aşk, arzu ve ihtiraslarla, şarap meclisiyle ve musikiyle anılır. Şu dizelerde olduğu gibi:

Utarit çamura saplanır, Zuhal ateşlere yanar, Zühre'nin kararı kalmaz da neş'e perdesini vurmaya başlar. (Gölpınarl1, 2000: 1/b. 684)

Bahtında sanki Zühre yıldızından inmişs saz söz yankılarl, göğsünde Davud gibi Zebur nağmeleri var. (Gençosman, 1974: rubai no: 1475)

Kimin bir yıldızla alâka ve merbuyeti varsa o; kendi yıldızıyla döner, dolaşır, o yıldızın tesiri altındadır.

Talihli Zühre ise şevki, çalıp çağırmayı, aşkı diler, onlara adamakıllı meyli vardır. (İzbudak, 2004: I/b. 751-752)

Bu gece benim gibi sevgilisini ariyan her gönül, Zühre gibi zevk ve sefaya yoldaştır!! (Gençosman, 1974: rubai no:113)

Ey İsa nefesli dudu kuşu, ey şirin sesli, güzel sesli bülbül, hadi o canlar katan nağmelerle Zühre'yi şaşkın bir hale getir, kendinden geçsin gitsin. (Gölpınarlı, 2000: I/62)

Zevk çalgıcın neş'e çengini okşayıp çalmaya başladı mı gökyüzündeki Zühre yıldızının kârı mı kalır, kazancı mı? (Gölpınarlı, 2000: I/2453)

Neden Zühre çalıp çığırmıyor dersin? (İzbudak, 2004: VI/b. 1724)

Ey Zühre yıldızl; gel de gönlümden saz ögrren! (Gençosman, rubai no. 702) çeng gelir.

Mevlâna Zühre'yi bazı müzik enstrümanları ile ilişkilendirmiştir. Bunların başında ney ve

Zühre'nin senin nağmelerinden başka daha hoş daha makbul nağmesi mi var, onun çaldı ̆̆ ney de nedir? $O$ senden nă̆me ögrenmek için dudă̆ını senin dudağına koymada. (Gölpınarlı, 2000: I/b. 290)

A Ay, cilvelerinle gece gündüz Zühre gibi çeng çalmadayım. (Gölpınarl1, 2000: VI/b. 2860)

Zühre’nin çengini al elinden, at taşları kadehine, sağrağına, kır gitsin. (Gölpınarlı, 2000: I/b. 2783)

Ney ve çengin yanı sıra bir Türk sazı olan kopuzun da Zühre'nin çalgısı olduğu görülür.

O ürkek Zühre yıldızı bendeki ateşi görünce kopuzunu bırakıp çabucak bir tarafa slvıştı! (Gençosman, 2004: rubai no: 106)

Aşağıdaki satırlar ise Zühre'nin şarapla ilgisini göstermektedir.

Zühre yıldızı senin şarap meclisinde değersiz bir halayıkcă̆ızdır. (Gölpınarlı, 2000: II/b. 3299)

Sus bu gece Zühre sâki oldu, kadeh sunuyor. Bizim pembe beyaz tenli sevgilimiz de kadehini aldı çekip duruyor. (Gölpınarlı, 2000: I/b. 261)

Hiç Zühre ylldızı, bir küçücük küpten şarap diler mi? (İzbudak, 2004: V/b. 3581)

Mecalis-i Seb'a'da geçen bir hikâyede ise Zühre ile Cuma günü arasındaki bağlantı dikkat çeker. Burada Müssteri ve Zühre yıldızlarından birlikte bahsedilir: "Müssteri yıldızı, gökyüzü bahçesinden çıkıp ovanın eteğinden lâle gibi parıldamaya, güzelim Zühre, İkizler burcu mumunun 
önünde, Ülker tezgâhında Çiğil güzellerinin giyecekleri ipek kumaşı dokumaya koyulunca" diyerek hikâyenin gerisi anlatılır. Gönlü Allah aşkıyla dopdolu Habib adlı birinin günlük iaşe konusunda ailesine karşı endişe ve mahcubiyeti üzerine bir Cuma günü büyük bir zatın vasıtasılyla Allah tarafından nasıl izzet ve ikrama mazhar olduğu, gönderilen hediyelerin ve değerli şeylerin evin dışına kadar taştığından söz edilir.(Gölpınarlı, http://dosyalar.semazen.net/e_kitap/Mecalis_i_Saba.pdf?iframe=true\&width $=60 \% \&$ height $=100 \%$, 2020). Bu hikâyedeki şahıs adı seçimi tesadüfî değildir. Habib "seven, sevgili" demektir. Mutasavvıfların arasında "Habibiye" denilen bir zümre vardır. Bunlar bir insanın yaratılmışlardan ilgisini keserek Allah'ı kendisine dost ve sevgili edindiğinde ondan dini yükümlülüklerin düşeceğini söylerler (Uludağ, 2005: 150).

İslam düşüncesinde Zühre'nin günü Cuma, Müşteri'ninki (Jüpiter) Perşembe'dir. Perşembe'yi Cuma'ya bağlayan gece ise Müslümanlar tarafindan mübarek sayılmıştır. Cuma "toplamak, bir araya getirmek" anlamındaki cem kökünden isimdir, aynı zamanda Kur'an'daki bir surenin ve haftalık ibadet gününün de adıdır. Hz. Peygamberin, "Güneşin doğduğu en hayırlı gün Cumadır; Âdem o gün yaratılmış, o gün cennete girmiş ve o gün cennetten çıkarılmıştır; kıyamet de Cuma günü kopacaktır" dediği rivayet edilir (Karaman, 1995: 85). İbn Arabi cem konusunu seyr ü sulûk ile ilişkilendirmiştir. Seyr ü sulûkun hedefi insanın dağılmış ve parçalanmış bütünlügünün yeniden kazandırılmasıdır (İbnü'l-Arabi, 2006: 262).

Müşteri ile Zühre ilişkisine vurgu yapan başka dizeler de vardır:

Ey yüzlerce Müssteri'nin Zühre 'si, ey Tanrı lütfunun sırrı, ey peri, hasede uğramamak için can ülkesine gizlice gel de al gönlü ele. (Gölpınarlı, 2000: I/b. 1785)

Müşteri ve Zühre'nin birleşmesine veya aynı burçta birbirlerine yakınlaşmalarına "sahip kıran" denir, kutluluk işaretidir. Urdu şair Atiş kadir gecesini Müşteri ve Zühre'nin birleştiği gece olarak yorumlamıştır (Schimmel, 2014: 256).

\section{Tartışma}

Mutlak hakikate veya yüce Tanrıya götüren yollar farklı kültürlerde farklı simgelerle anlatılmaya çalışılmıştır. Büyüklük, ezelilik, ebedilik, şekilsizlik gibi Yüce Tanrı'ya ait sıfatlar onun gök ile özdeşleştirilmesine sebep olmuş, günlük hayatta yüksek bir yere çıkabilmek için kullanılan ip, merdiven, sarmaşık gibi nesneler manevi yükselişin sembolleri olarak kullanılmıştır. Yüce gerçeğe ulaşmak bazen ağaca veya dağa tırmanmak olarak, bazen de örümcek ağı şeklinde hikâye edilmiştir (Eliade, 1992:29). "Yüksekte" veya "yükselmiş" olan hangi dini sistemde olursa olsun aşkın olanı temsil etmektedir (Eliade, 2003:24).

İşte bunlar gibi gökyüzü de insanın Tanrıya doğru olan yolculuğunun seyrini anlatmak için kullanılan bir vasıta olmuştur. Göğü gözleyen antik insanlar yedi göksel nesnenin pozisyonlarını değiştirdiklerini, sabit yıldızların değişmeyen arka planlarına karşı hareket ederek yerlerini değiştirdiklerini tespit etmişlerdir. Bunlar Güneş, Ay, Mars, Merkür, Jüpiter, Venüs ve Satürn'dür (Zell-Ravenheart, 2004: 137). Bu yedi gezegen antik Misır, Roma, Yunan, Çin, Cermen, Aztek ve Maya gibi uygarlıklarda farklı isimlerle var olmuşlardır. Bilimsel alanda günümüzde kullanılan gezegen isimleri Romalılar tarafından verilenlerle aynıdır. Bu isimlerin Romalıların tanrı veya tanrıçalarına verilmelerinin nedeni ise onların yeryüzünden görünüşleriyle alakalıdır. Mesela Merkür diğer gezegenlere nazaran özellikle hızlı hareket ettiği için habercidir. Zühre'nin Batı mitolojisindeki karşıllı̆ı olan Venüs, Güneş ve Ay'dan sonra gökteki en parlak ve güzel cisimdir. Mars kanın rengi olan kırmızı renkli gözüktüğünden savaşçıdır. Jüpiter en büyük ve güçlü gözükendir (Elkins-Tanton, 2006: 9). Bu yıldızların insan formuna sokulan tanrı veya tanrıçalarla özdeşleştirilmesi yoluyla ruhsal yükselişin sırları verilmeye çalışılmıştır. Jüpiter, Venüs, Merkür ve diğerleri tanrıdırlar ama aynı zamanda gezegendirler. Bilindiği üzere tanrılar gerek fiziksel yaradılış özellikleri gerekse tabiat veya 
mizaçları yönünden aynı insanlar gibidirler. Bu yüzden onlar bir taraftan isimlerini gök cisimlerinden alırken diğer taraftan da insanın duygu ve hislerinin müşahhaslaştırılması olarak da düşünülmelidir. Mesela savaş tanrısı olan Mars aynı zamanda öfke ve hiddetin müşahhaslaşmışıdır, askeri bir karakterdir, aynı zamanda savaşçı bir karakterdir. Merkür idrakin, zihin gücünün, anlık kavrayışın, Venüs ise güzellik ve aşkın müşahhaslaşmışıdır vb. (Jung, 2005: 735) Böylesi önemli bir görev atfedilen yıldızlar yeryüzünden küçük ve bazen de zayıf veya soluk görünmelerinden ötürü daha sonraları haftanın günleri ile ilişkilendirilmişlerdir. Haftanın yedi günü muhtemelen dünyanın ilk organize uygarlığı olan Mezopotamya (bu günkü Irak’ta MÖ.3500) orjinlidir. Roma imparatorluğu bundan neredeyse 4000 yıl sonra, yaklaşık MS.321'lerde onu benimsemiş ve daha sonra bu Batı Avrupa yoluyla yayılmıştır (Elkins-Tanton, 2006: 9). Bu gök cisimlerinin içinde en parlak olanları güneş ve ay olduğu için haftanın birinci ve ikinci günlerine onların adı verilmiştir (Zell-Ravenheart, 2004: 137). Bunlar günümüzde de mesela İngilizcede Sunday, Monday, Almancada Sontag, Montag yani güneş günü, ay günü olarak devam etmektedirler. Salı Mars'1n, Çarşamba Merkür'ün, Perşembe Jüpiterin, Cuma Venüs'ün günüdür (Elkins-Tanton, 2006: 9).

Şimdi burada hikâyeyle ilgili başka bir hususa, Harut ile Marut'un baş aşağı asıldıkları Babil kuyusu konusuna değinmek istiyoruz. Çünkü Babil sözcüğü bu iki meleğin isimleri ile beraber Bakara 102'de geçmektedir. İlginç bir şekilde Tevrat'ta Babil'den dillerin karıştırıldığı yer olarak söz edilir. Buradaki ifadelere göre başlangıçta insanların kullandığı tek bir dil varmış. Herkes aynı dili kullanır ve birbirlerini anlamakta hiç problem yaşamazlarmış. Bir gün bu insanlar büyük bir kent kurup, göklere kadar ulaşacak bir kule yapmaya niyet etmişler; böylece yeryüzüne dağılmayacaklarını düşünmüşler. Tanrı yeryüzüne inmiş, onların ne yaptıklarına bakmış ve bu işe razı olmamış, onların dillerini karıştırmış, işçiler birbirlerinin ne dediklerini anlamaz olmuşlar. Şehir inşa edilememiş ve insanlar yeryüzüne dağılmışlar (Yaratılış, 11: 1-9). İbranice'de balal sözcüğü "karıştırmak" anlamına geldiğinden bu kente "dillerin karıştırıldığı yer" anlamında Babil denildiği söylenir. Tarihsel bilgilere göre ise Sümerliler bundan yaklaşık beş bin yıl önce Bab-ilu yani "Tanrı Kapısı" anlamına gelen Babil'de, Tanrı Marduk adına böyle bir kule/ziggurat inşa etmişlerdir (Doniger, 1999: 104). Bu yapı temelde 100 metreye yayılan ve yükseklikte 91 metreye ulaşan yedi katlı bir kule şeklindedir (Black ve Green, 2004: 179). Bu yapı merkez simgeciliğine bir örnektir. Babil, Göksel Kudüs'ün veya cennetin tersine, düşmüş ve yozlaşmış bir varoluşun görüntüsüdür. Ezoterik anlamda o, somut olanı veya materyal dünyayı temsil eder ki, nefsin evrimi ya da başka bir deyişle ruhun maddeye nüfuzu ve onu terk etmesi burada gerçekleşir (Cirlot, 2002: 22). Hz. Mevlâna bu bağlamda akıl meleğinin Harutlaşması durumunda insanın da Harut gibi düşüşünden söz eder. Harutlaşınca da onun kötü insanlara sihir öğreteceğini söyler. Ona göre insan cüz'i aklı ya da heva ve hevesini kendine vezir yaparsa düşeceği durum bu meleklerin durumuna benzer, asla yükselişi/Tanrı'ya ulaşması söz konusu olamaz (Gölpınarlı, 1985: IV/b. 1255-57).

Yeniden Mevlâna'nın eserlerindeki Zühre imajına dönecek olursak; bilindiği üzere Mevlâna bir mutasavvıftır. Tasavvufun konusu ise Allah aşkıdır. Onun Zühre karakteri ile anlatmaya çalıştığı şey de elbette ki bir gezegenin yaradılış süreci değil, spritüal aşkın bir örneğidir. Zühre burada bir hiyerofanidir, mutlak hakikate ulaşma yolculuğunda salikin Zühre yıldızının özellikleriyle sıfatlandığı güzellik ve aşk makamıdır. Tasavvufta hubb-u ruhani olarak bilinen bu aşk bir kadının ancak metamorfoza uğrayarak yıldıza dönüşmesi durumunda olduğu gibi insanı ruhen değiştirip dönüştüren bir haldir. Bu durum değersiz madenleri altına çevirmek için felsefe taşını arayan orta çağ simyacılarının durumuyla karşılaştırılabilir. Nitekim Mevlâna da bundan söz eder: "sen de bakır varliğının altına dönmesini istiyorsan, onlarla (Allah âsşlklarıyla) birlikte ol, çünkü onlar kimyadır" der (Can, 2005: rubai no. 777). Buradaki değişim dönüşüm, yani Zühre'nin yere ait bir unsurken göğe ait bir unsur haline gelmesi, toprak bedenden ışık bedene terfi etmesi, hayvani tabiatın ölmesi ve ruhani olana doğuş şeklinde anlaşılabilir. Doğum ise dişi ile özdeşleşen bir kavramdır. Dolayısıyla burada Zühre'den maksadın her insanın özünde var olan dişil prensip olduğunu söyleyebiliriz ki Kur'an'da "biz sizi bir erkekle bir dişiden yarattık" (Hucurat 49/13) deniyor. Doğada değişim, 
dönüşüm, üretkenlik, yaratıcılık gibi kavramların müşahede edilebildiği varlık dişilerdir. Bunun gibi ruhsal değişim, dönüşüm ve doğumu sağlayan da insandaki dişil prensiptir. J. Campbell, Kant terminolojisinde "dişi"nin duyarlılık formları denilen şeyleri temsil ettiğini söyler (Campbell ve Moyers, 2009: 217). Eliade ise bir mitte veya ritüelde "kadın" ile kastedilen şeyin Homo Sapiens'in dişil cinsi olmayıp kozmik prensibin cisimleşmişi olduğunu, canlandırdığı kozmik bir ilkeyi temsil ettiğini söyler (Eliade, 2003: 401). İslam tasavvufunda nefsin kadınla temsil edilmesi çok iyi bilinir. İbnü'l-Arabi “Âlemde erkek diye bir şey yoktur” derken aslında yaratılmış olmak bakımından, herkesin Tanrı karşısında dişi yani edilgenlik mertebesinde olduğunu ifade eder (İbnü'l-Ârabi, 2006: 267). Kadın kavramı ile ilgili olarak Mevlâna'da da bu görüşlere denk ifadeler vardır. Mesela Mesnevi'nin bir yerinde şöyle der: “Ĕger Tanrı'nın işaretlerine burun büküyorsan kendini erkek mi sanıyorsun? Dikkat edersen anlarsın ki kadınsın (İzbudak, 2004: I/b. 944). Bir başka eserinde de: "âşık olmayan herkes mânâ bakımından kadındır; hem de bak da gör, ne çeşit kadındır onlar, ne çeşit sözlere dalıp gitmişlerdir" (Gölpınarlı, 2000: III/b. 947) diyerek erkeklik veya dişilik kavramlarının toprak bedenin şekliyle alakalı olmadığını söyler. Divanı Kebir'de bu fikri destekleyici mahiyette şu dizeler yer alır:

A erkekliği kalmamış kişi, Tanrı eri olursan gönülden gelinler coşar, çıkar. Göz pınarından Ay gibi, Zühre gibi, Güneş gibi, Ülker yıldızı gibi periler baş gösterir (Gölpınarlı, 2000: VI/b. 25632564).

Dini hikâyelerde ve mitolojilerde bu tür ruhsal aşka sarhoşluk, coşku, neşe ve sevinç eşlik eder. İslam tasavvufunda ise bu sarhoşluk haline "sekr" denir. Zühre'nin şarap, musiki ve muhabbet ile anılması bundandır. Zühre şarap meclislerinin sâkisidir. İslam'da sözel olarak ama diğer kültürlerde aynı zamanda görsel olarak da ifade edilmeye çalışılan bu tanrısal/kutsal sarhoşluk ve şarap, dünya şarabı ve onun verdiği sarhoşlukla karıştııılmamalıdır. Bu şarap Kur'an'da cennetliklerin içeceği söylenen şerâben tahûran/temiz içecek'tir (76 İnsan, 21). İslam inancında cennette akan dört ırmaktan birisi şarap ırmağıdır ki bu mutasavvıflara göre Allah aşkıyla mestliği ve muhabbeti simgeler. Bu kutsal içecek farklı kültürlerde farklı isimlerle ortaya çıkmıştır. Hintlilerin Soma'sı, İranlıların Haoma'sı tanrısal kökenli içeceklerdir. Eski Yunan dininde tanrı Dionysus adına yapılan şölenlerde ise bol bol kutsal içecek olarak şarap kullanılmıştır. İçenlere ölümsüzlük vereceğine inanılan bu sıv1 "tanrısal öz"dür, çünkü yaşamı" mutlak gerçekliğe" dönüştürmektedir. Kutsal sarhoşluk tam olarak olmasa da ilahi varlık kipine katılmayı sağlar; yani paradoksal olarak aynı anda hem varlığın bütünlügüne sahiptir hem de oluşmaktadır (Eliade, 2003: 174). Nitekim Mevlâna "can şarabı" adını verdiği bu içecek için şu nitelemeyi yapmaktadır:

Nerede topraktan meydana gelen şarap, nerede can şarabı? Bu dünyanın şarabı da mezesi de dünya gibi vefasız... Tanrı şarabı, Tanrı sağrağı, Tanrı gibi ölümsüz. (Gölpınarlı, 2000: VII/b. 3340-3341).

Müzikal enstrümanlar ise çok eski çağlardan beri aşkın sembolü olarak kullanılmışlardır. Hatta Rönesans dönemi astrologları müzisyenler ile âşıkların "Venüs'ün çocukları" olduğuna inanmışlardır. Antikiteden beri üflemeli çalgılara seksüel bir önem verilmiş, bu daha sonra telli olanlara da geçmiştir (Pinson, 1998: 635). Dünyevi aşkla bağlantılı bütün bu durumlar manevi aşk1 anlatırken de kullanılmıştır. Musiki aletlerinde de durum farklı değildir. Mesela sema ayinlerinin baş enstrümanı insanı kâmili simgeleyen neydir. Burada Zühre'nin çalgısı olarak karşımıza çıkan çeng ise telli bir enstrümandır ve Batılıların müzik aletlerinden harba benzer (Cebecioğlu, 2004: 54; Güldaş, 1993: 635). Çeng çalgısı kadın simgesi olarak da kullanılmıştır. On altıncı yüzyılda yaşamış Tarihçi Gelibolulu Mustafa Ali yaşadığı dönemdeki müzik aletlerini sınıflandırırken onları erkek ve dişi olarak ayırmış, çengi "dişil çalgılar" grubunda değerlendirmiştir (Beşiroğlu ve Koçhan, 2008: 127). Onun kadın ile ilişkilendirilmesinin sebeplerinden biri uzun tellerinin kadının saçlarına benzetilmesi olabilir. Çengin köşeli bir yapısı vardır. Bu yüzden özellikle tasavvufta ve divan 
edebiyatında sevgilinin cefaları karşısında iki büklüm olmuş âşıkları temsil etmek üzere kullanılmıştır (Özkan, 2007: 484).

Müslümanlar arasında Zühre'nin fiziksel kadın güzelliğinin ve şehvetin temsilcisi olmasından, içkiyle müzikle ilişkisinden dolayı ona karşı negatif tavır sergileyenler de olmuş (Lingwood, 2014: 153) ve bu durum dişil cinsin toplumsal cinsiyet rollerine de yansımıştır. Bunları din dilinin metaforik özelliğinin kavranamayışına hasrediyoruz. Din dilinde er ve dişi kavramlarının ne ifade ettiği ortaya çıkmadıkça kadına karşı olumsuz tavırların süreceği aşikârdır. Oysa Divan Edebiyatına bakıldığında dahi görülecektir ki kadın hep maşuktur, erkek hep âşıktır. Tasavvufta insan âşıktır, Tanrı maşuktur.

\section{Sonuc}

Mevlana'nın çoğu eserlerini tarayarak edindiğimiz bu bilgilerden çıkardığımız sonuçlanı birkaç madde halinde toplayabiliriz: 1- Zühre'nin göğe yükselip bir yıldıza dönüşmesi hikayesi pek çok dini gelenekte anlatılan insanın manevi aleme veya cennete yükselme sürecinin bir örneğidir. Aslında bu yükseliş her zaman bir düşüş ile beraberdir. Çünkü düşme olmadan yükselme gerçekleşemez, tıpkı gece olmadan gündüzün olmayacağı gibi. Bu yüzden Zühre'nin hikayesi de aslında bir düşüş hikayesi ile birliktedir. Harut ve Marut adlı meleklerin düşüşü Zühre'nin yükselişi demektir. Bu yüzden Mevlâna Zühre'nin adını bu meleklerle birlikte zikreder. Düşüş ve yükselişin başladığı yer ise "Tanrı Kapısı" anlamındaki Babil kenti ile simgelenmiştir. Harut ve Marut'un düşüşlerine neden olan şey şehvetlerine yenilmeleri, gurur ve kibre kapılmaları ve aklı selim ile karar verememeleridir. Diğer taraftan Zühre'nin yükseliş sebebi, işlediği bir suçtan dolayı utanması, pişmanlık duyması ve tövbe etmesidir. Tövbe etmek ise manevi yükselişteki başlangıç noktasıdır. Zühre'nin şahsında utanma ile başlayıp yıldıza dönme ile sonuçlanan bu süreçte, metaforik olarak, İslam Tasavvufunda "seyr" denen insanın Allah'a giden manevi yolculuğu ve ulaşılan makam/derece anlatılmıştır. 2- $\mathrm{Bu}$ makam aşk ve güzellik makamıdır. Bu makamın bir kadın tarafından elde edilmesi tasavvufta nefsin kadın ile simgelenmesinden ötürüdür. Metnin içinde ayrıca Mevlana'nın kimleri kadın olarak adlandırdığından söz etmiştik. Gelinen bu makamın muhteşemliği Zühre'nin güzelliği ile, sürece eşlik eden davranışlar ise sarhoşluk ve musiki ile simgelenmiştir. 3- Zühre'nin günü Cuma'dır. Bu Müslümanlar için “toplanma günü”dür. Dolayısıyla Zühre makamı aynı zamanda bir toplanma makamıdır, yani maddenin cazibesi ile dağılan, savrulan duyguların ve parça buçuk olan aklın yeniden toparlanması birlik olmasıdır. Bu durum ruh için büyük mutluluk ve neş'e, adeta bayram günüdür.

Din dili metaforik bir dildir. O yüzden Zühre'nin hikâyesi bir kadının değil ister erkek ister kadın olsun, Tanrı'ya ulaşma yolunda herkesin hikâyesidir. Dini kıssaların vermeye çalıştıkları mesajları anlayabilmek için onlardaki imgelerin her birimizin içindeki ruhsal potansiyelin yansımaları olarak görülmesi önem arz etmektedir. Bizim maneviyatımıza dair haller yani fizik ötesi durumlar, dinlerde veya mitolojilerde bizim beş duyu organımızla algılayabileceğiz ve aklımızla kavrayabileceğimiz şekilde fiziksel gerçekliklere dönüştürülerek anlatılmıştır. Mistik geleneklerin amaçları da insanları Tanrı ve uhrevi âlem konusunda daha derin bir farkındalığa ulaştırmaktır.

\section{Kaynakça}

Beşiroğlu, Ş. Şehvar- Koçhan, Günay. (2008). “Çeng: Bir Çalgının Toplumsal Cinsiyet Üzerinden Kadın Simgesi Olarak Kuzey Hint, Timur ve Osmanlı Saraylarındaki Görsel Malzemeler Üzerinden Değerlendirilmesi”. ICANAS 9/1. Kültür Bakanlığı Yayınları. 127-139.

Black, Jeremy- Green, Anthony. (2004). Gods, Demons and Symbols of Ancient Mesopotamia. The British Museum Press. 
Campbell, Joseph-Moyers, Bill. (2009). Mitolojinin Gücü. Çev. Zeynep Yaman. Mediacat Yayıncilik.

Cebecioğlu, Ethem. (2004). Tasavvuf Terimleri ve Deyimleri Sözlüğü. Anka Yayınlar1.

Cirlot, J.E. (2002). A Dictionary of Symbols, trans. Jack Sage. Dover Publications.

Çaycı, Ahmet. (2002). Anadolu Selçuklu Sanatında Gezegen ve Burç Tasvirleri. Kültür Bakanlığ1 Yayınları.

Demirci, Kürşat. (2997). "Harut ve Marut”, TDV İslam Ansiklopedisi, C: 16, TDV Yayınları, 262264.

Eliade, Mircea. (1992). Imgeler Simgeler. Çev. M. Ali Kılıçbay. Gece Yayınları.

Eliade, Mircea. (2003). Dinler Tarihine Giriş. Çev. Lale Arslan. Kabalcı.

Elkins-Tanton, Linda, T. (2006). Jupiter and Saturn. Infobase Publishing.

Güldaş, Ayhan. (1993). “Çeng”, TDV İslam Ansiklopedisi. C: 8, TDV Yayınları. ss. 268-269.

İbnü'l- Ârabi. (2006). Fusûsu'l-Hikem, Çev. ve Şerh. Ekrem Demirli, Kabalc1.

Jung, C., Gustav. (2005). Visions: Notes of the Seminar Given in 1930-1934. Ed. Claire Douglas, Routledge Press.

Karaman, Hayreddin. (1995). "Cuma”, TDV İslam Ansiklopedisi. C: 8, TDV Yayınları. 85-89.

Kitab-ı Mukaddes Çevirisi, (1988). Kitab-1 Mukaddes Şirketi.

Kur'an-ı Kerim

Lingwood, G., Chad. (2014). Politics, Poetry, and Sufism in Medieval Iran: New Perspectives on Jāmī’s Salāmān va Absāl. Brill.

Merriam -Webster's Encyclopedia of World Religions (1999). Ed. Wendy Doniger, MerriamWebster.

Özkan, Ömer. ((2007). Dîvân Şiirinin Penceresinden Osmanlı Toplum Hayatı. Kitabevi Yayınları.

Pinson, Yona. (1998). "Music" Encyclopedia of Comparative Iconography, vol.II. Ed. Helene E. Roberts, Fitzroy Dearborn Publishers. 629-639.

Rûmî, Mevlâna Celâleddin. (1974). Rubailer. Çev. M. Nuri Gençosman. Milli Eğitim Basımevi,

Rûmî, Mevlâna Celâleddin. (2005). Rubailer. Çev. Şefik Can. İl Kültür Turizm Müdürlügü Yayınları.

Rûmî, Mevlâna Celâleddin. (2000). Divanı Kebir. Haz. Abdülbaki Gölpınarlı. Kültür Bakanlığı Yayınları.

Rûmî, Mevlâna Celâleddin (2004). Mesnevi. Çev. Veled İzbudak. Konya Büyükşehir Belediyesi Kültür Yayınları.

Rûmî, Mevlâna Celâleddin. (1985). Mesnevi. Çev. ve Şerh: Abdülbaki Gölpınarlı. Milli Eğitim Basimevi.

Rûmî, Mevlâna Celâleddin. Mecâlis-i Seb'a, (5. Meclis'te). Çev. Abdülbâki Gölpınarl1, http://dosyalar.semazen.net/e_kitap/Mecalis_i_Saba.pdf?iframe=true\&width=60\%\&height $=100 \%$ Erişim:21.01.2020

Sarı, Emre. (2016). Türk Mitolojisi, Nokta E-Book. 
Schimmel, Annemarie. (2014). Two Colored Brocade: The Imagery of Persian Poetry. UNC Press Books

Schimmel, Annemarie. (2001). İslamın Mistik Boyutları, Çev. Ergun Kocabıyık, Kabalcı.

Uludağ, Süleyman. (2005). Tasavvuf Terimleri Sözlüğ̈̈. Kabalcı Yayınları.

Yitik, Ali İhsan. (2000). "Hz. Meryem ve Efes-Meryemana Evi”. Firat Üniversitesi Illâhiyat Fakültesi Dergisi. V: 55-71.

Zell-Ravenheart, Oberon. (2004). Grimoire for the Apprentice Wizard. Career Press. 